los planes de estudio en curso. Sería ilusorio, aunque resulte deseable, que aspectos eminentemente prácticos, como el patrimonio y las técnicas audiovisuales, tuvieran cabida allí. Probablemente la cuestión pendiente, y en la única que se pueda alcanzar una cierta eficacia es en la formación de posgrado, siempre que ésta mantenga los niveles de calidad que le falta a la Universidad pública. En este sentido es preciso elevar los niveles de exigencia para los alumnos que aspiran a los mismos, y de autoexigencia para el profesorado que los imparte. Ahí si cabe proponer títulos de magister y/o experto en patrimonio y etnología, y técnicas audiovisuales y/o etnología.

Por supuesto, no se puede pretender que la formación de un antropólogo responda sólo a las exigencias académicas, en muchas ocasiones excesivamente solipsistas, sino al necesario sentido práctico de la disciplina, cuya existencia social se justifica, entre otras poderosas razones, por la pretensión de ser una suerte de ingeniería cultural, capaz de contribuir a la solución de los numerosos y complejos problemas de las sociedades contemporáneas.

Diremos finalmente, que debido seguramente a la larga tradición de ensimismamiento nacional y regional, nuestros antropólogos están faltos de terrenos de estudio exteriores a nuestra comunidad, lo cual es observado por los profesionales más exigentes, como una grave anomalía en la pequeña historia de la antropología europea, y en segundo lugar, se con- templa igualmente una falta de destreza conceptual en el ámbito de la construcción de la sociedad internacional del conocimiento, de la cual estamos absolutamente ausentes. Estos déficits que producen a la larga inexplicables rechazos de las aportaciones foráneas a la antropología de Andalucía, sólo tiene una solución a medio plazo: que los estudiantes se incardinen cada vez con los programas europeos de colaboración universitaria. Además de este esfuerzo formador, yo propondría incluso una suerte de terapia colectiva: sugerir a nuestros estudiantes que no hagan trabajos de investigación sobre Andalucía, y que consagren sus energías a comprender otras sociedades, siguiendo los cánones tradicionales de formación de antropólogos, vigentes desde el inicio de la disciplina. Incluso portugueses e italianos, por no decir franceses e ingleses, nos sacan en esto mucha ventaja. La pereza nos sigue venciendo en cuanto apertura hacia el exterior, aunque la recubramos de vagas alusiones al "anticolonialismo" de nuestras proposiciones.

Por los demás, sólo cabe felicitarse por la transformación que se ha operado en la formación de antropólogos en estas dos décadas, que van de 1982 a 2002, con el paso del amaterismo a la profesionalización, y desear que en las dos que siguen, seamos capaces de estar a la altura de la sociedad europea y mediterránea, a las cuales nos debemos. Se ha avanzado mucho, pero todavía sigue siendo insuficiente.

\title{
La Antropología en la tutela del patrimonio
}

Fuensanta Plata García

Concha Rioja López

Conservadoras del Patrimonio Etnológico

Hay disciplinas en el contexto europeo, no así en el americano, que parecen condenadas al ámbito universitario. Una de ellas es la Antropología que, salvo en la esfera museística en la que ha participado desde sus orígenes', excepcionalmente ha desenvuelto su actividad en otras esferas lo que suscita, a niveles subliminales si se quiere, la cuestión sobre la "pureza" o no de la actuación de los antropólogos en ámbitos ajenos a la Universidad.

Para los que desde que terminamos la carrera no teníamos vocación docente y hemos tenido que afrontar un mercado de trabajo cada vez más difícil, esta cuestión ha tenido que ser obviada ante la realidad que se nos ofrecía. Salvo contados casos en los que la fortuna personal ha permitido la elección de lo que uno quería dedicarse, como el caso de Caro Baroja, los demás mortales hemos trabajado en lo que ha ido surgiendo sin poder hacer demasiados remilgos a que lo ofertado se ciñera o no al campo teórico y metodológico de la Antropología. La realidad de la calle y la realidad de la Universidad son dos realidades en nuestro país, todavía hoy, un tanto paralelas. Lo idóneo es que llegaran a ser confluentes y cada una aportara a la otra el enriquecimiento que supone la variedad de posturas en la línea de lo que la Antropología ha querido, desde sus orígenes, enseñar a la Humanidad, es decir, que la variedad es enriquecimiento y no exclusión. Si algo podemos tener en común los antropólogos de una u otra línea es el carácter que nos imprime la propia disciplina a la que nos dedicamos y esto se va a traslucir en cualquier actuación sea del campo que sea.

Ciñéndonos al campo de la tutela de Patrimonio 2, el acceso a la Función Pública ${ }^{3}$ para el antropólogo, al igual que para el resto de las especialidades, se realiza mediante oposición al Cuerpo Superior Facultativo, opción Conservadores del Patrimonio Histórico. Esta opción se encuentra a su vez dividida en especialidades (Arqueología, Historia del Arte, Arte Contemporáneo, Patrimonio Inmueble). 
Hasta la fecha se han producido 4 tres oposiciones por el sistema libre, uno mediante el sistema de concursooposición ${ }^{5}$, cuyo proceso se encuentra detenido actualmente, y una de promoción interna 6 . Mediante este procedimiento solo hemos ingresado dos.

Como Conservadores de Patrimonio, el trabajo de los antropólogos va a girar en torno a las siguientes tareas:

- Supervisión y dirección de trabajos de redacción de las documentaciones técnicas reglamentarias de los expedientes de catalogación de Patrimonio Etnológico.

- Elaboración de documentaciones técnicas de Patrimonio Etnológico.

- Seguimiento y dirección de definición y delimitación de Conjuntos Históricos.

- Elaboración de informes técnicos sobre propuestas de incoación en materia de Etnología.

- Informes sobre solicitudes de exportación de bienes muebles de carácter etnológico.

- Coordinación de propuestas y seguimiento de elaboración de inventarios de bienes inmuebles, muebles y actividades de interés etnológico.

- Informes, seguimiento, directrices de los catálogos, planes, programas, proyectos de planeamiento urbanístico, medioambiental y de otras administraciones que incidan en el Patrimonio Etnológico.

- Informes de proyectos de intervención con incidencia en Lugares de Interés Etnológico, Monumentos, Conjuntos Históricos, Sitios Históricos, Jardines Históricos y bienes muebles.

- Control y seguimiento de obras en bienes del Patrimonio Histórico de carácter etnológico.

- Seguimiento y coordinación de la Comisión Asesora de Etnología.

- Informes técnicos previos, de contenido etnológico, a las sesiones de las Comisiones Provinciales de Urbanismo y Ordenación del territorio y de las Comisiones de Patrimonio Histórico.

- Programación y seguimiento de los planes anuales de investigación etnológica.
- Coordinación y seguimiento de los anuarios y publicaciones de Patrimonio Etnológico.

- Informes técnicos a procesos legales relacionados con el Patrimonio Etnológico.

Del amplio abanico que exponemos y dado el escaso número de antropólogos funcionarios, que se reduce a las abajo firmantes, se infiere la necesidad de nuevas convocatorias de acceso a la Función Pública que vayan dotando a nuestras Delegaciones provinciales de un personal fijo y cualificado. Con todo, la incorporación, mediante contratos de Consultoría y Asistencia Técnica, de un antropólogo por Delegación, que el año pasado fue de manera parcial y este año a tiempo completo, ha supuesto un gran logro.

Como puede observarse por la relación de las tareas que debe afrontar el antropólogo en la tutela del Patrimonio Etnológico, su formación debe ser muy amplia abarcando desde las propias técnicas de investigación de campo, propias de la Antropología, a las más específicas derivadas de su trabajo en la Administración con lo que esto implica sobre todo en materia legal. Con todo, la propia dinámica de las demandas del trabajo obliga a una formación continua que se genera en el día a día que no puede aprenderse, totalmente, ni en la Universidad ni en los libros.

No tratamos de asustar a los posibles aspirantes sino al contrario animarlos a enrolarse. Queremos transmitirles que si bien las facetas son muchas, igualmente es mucho el disfrute por la variedad temática del Patrimonio que tutelamos, por lo novedoso de los planteamientos y situaciones, por la implicación y el respaldo (mayoritario) o el rechazo social que implica cada proceso de protección y, sobre todo, por la convicción de que estamos trabajando con el Patrimonio que mas claramente representa las formas de vida de Andalucía.

\section{Notas}

I. No es corporativismo considerar que fueron las primeras colecciones etnográficas, por su vertiente exótica, tan importante en los primeros contactos de los descubrimientos, el origen de lo que, posteriormente, se convertiría en la institución museal. De hecho constituyeron una parte importante de los fondos que formaban las primitivas wunderkamer - cámaras de las maravillas- de los coleccionistas que desde el siglo XVI surgen por toda Europa.

2. Aunque dentro del campo de la tutela patrimonial, no vamos a tratar la figura y el papel de los Conservadores de Museos por su propia especificidad.

3. Decreto 264/1989, de 27 de Diciembre, por el que se regula el procedimiento de acceso a la condición de funcionario de la Administración de la Junta de Andalucía.

4. ORDEN de 6 de septiembre de 1990, por la que se convocan pruebas selectivas para ingreso en el cuerpo Superior
Facultativo, opción: Conservadores de Patrimonio Histórico. ORDEN de 18 de enero de 1993, por la que se convocan pruebas selectivas para ingreso en el Cuerpo: Superior Facultativo, opción: Conservadores del Patrimonio Histórico.

ORDEN de 19 de febrero de 1998, por la que se convocan pruebas selectivas para ingreso en el Cuerpo Superior Facultativo, Opción Conservadores del Patrimonio Histórico.

5. ORDEN de 17 de septiembre de 1998, por la que se convocan pruebas selectivas por el sistema de concurso-oposición libre para ingreso en el Cuerpo Superior Facultativo, Opción Conservadores del Patrimonio Histórico.

6. ORDEN de 8 de julio de 1998, por la que se convocan pruebas selectivas, por el sistema de promoción interna, para ingreso en el Cuerpo Superior Facultativo, Opción Conservadores del Patrimonio Histórico. 